\title{
Krisis Legitimasi Politik Donald Trump Sebagai Ancaman Supremasi Amerika Serikat Dalam Politik Global
}

\author{
Ahmad Sahide $^{1}$ \\ ahmadsahidie@gmail.com
}

\begin{abstract}
Abstrak
Donald Trump adalah Presiden ke-45 Amerika Serikat yang dilantik pada tanggal 20 Januari 2017. Kemenangan Donald Trump mengguncangkan tatanan politik global karena sejumlah pernyataan dan kebijakan politiknya yang sangat kontroversial. Sejumlah kebijakan Trump yang kontroversial diantaranya meliputi pengakuan terhadap Jerusalem sebagai ibu kota Israel, kedekatan hubungan dengan Vladimir Putin, hingga kebijakan proteksionisme yang mendapatkan resistensi dari dalam dan luar negeri. Penulis menggunakan teori legitimasi dalam kajian ini untuk melihat dampak politik dari kebijakan yang diambil oleh Trump. Hasil dari kajian ini melihat bahwa kontroversi kebijakan Donald Trump ini berdampak pada krisis legitimasi politik yang berakibat pada terancamnya supremasi politik AS dalam kancah politik global.
\end{abstract}

Kata Kunci: Donald Trump, Dunia Islam, Kontroversi, Legitimasi, Supremasi Politik. Amerika

\begin{abstract}
Donald Trump is the 45th President of the United States who was sworn in on January 20, 2017. Donald Trump's victory shook the global political order because a number of his statements and political policies were very controversial. A number of controversial Trump policies include the recognition of Jerusalem as the capital of Israel, the closeness of relations with Vladimir Putin, to protectionist policies that get resistance from within and outside the country. The author uses the legitimacy theory in this study to see the political impact of the policies taken by Trump. The results of this study see that Donald Trump's policy controversy has an impact on the crisis of political legitimacy which results in the threat of US political supremacy in the global political arena.
\end{abstract}

Keywords: American Political Supremacy, Controversy, Donald Trump, Islamic World, Legitimacy

\section{Pendahuluan}

Hasil pemilihan Presiden Amerika Serikat (AS) yang berlangsung pada tanggal 8 November 2016 cukup mengejutkan dunia internasional. Hal itu tidak terlepas dari kemenangan Donald Trump sebagai kandidat dari Partai Republik, yang sekaligus menggagalkan upaya Hillary Clinton untuk menjadi presiden perempuan pertama di AS. Kemenangan Donald Trump menimbulkan kekhawatiran dunia internasional, terutama

1 Korespondensi: Program Studi Magister Ilmu Hubungan Internasional, Universitas Muhammadiyah Yogyakarta, Jl. Brawijaya Tamantirto Kasihan Bantul 5518, Gedung Pascasarjana Lt. 1 Kampus Terpadu, 0274-387656 Ext. 247 
dunia Islam, karena selama masa kampanye, Trump seringkali mengeluarkan pernyataan politik berupa rencana pembatasan masuknya imigran dari dunia Islam ke Amerika (Sahide, 2018: 38). Tidak heran, respons dunia internasional sangat negatif begitu Trump dipastikan memenangi pilpres Amerika berdasarkan electoral vote yang melebihi 270 suara. Respons negatif itu terlihat dengan langsung anjloknya harga saham Eropa tidak lama setelah Trump memeroleh suara electoral vote yang melebihi 270 suara. Nilai tukar dollar Amerika juga jatuh. Walaupun kemenangan ini juga tidak disangka oleh Trump dan timnya (Donald Trump and his tiny band of campaign warriors were ready to lose with fire and fury. They were not ready to win) (Wolff, 2018: 21).

Di dalam negeri, aksi massa terus berlangsung pada awal terpilihnya Trump sebagai Presiden AS ke-45. Hal ini tentu jarang terjadi dalam demokrasi Amerika yang menganut paham demokrasi bahwa suara rakyat suara Tuhan. Bahwa mereka tidak menerima hasil pemilihan yang demokratis itu menunjukkan adanya protes terhadap 'suara Tuhan' dan ini menjadi catatan tersendiri akan adanya cacat dari demokrasi di negara tersebut. Adanya respons negatif dari dunia internasional begitu Trump dinyatakan menang dalam pemilihan Presiden Amerika dan juga demonstrasi penolakan yang berlangsung hingga pada awal terpilihnya tentunya berdampak pada krisis legitimasi politik Trump, baik itu dari dalam negeri maupun dari luar negeri, dan terutama dari dunia Islam karena kontroversi kebijakan politiknya.

Berangkat dari latar belakang diatas, tulisan ini akan berfokus pada pemaparan mengenai kaitan antara kebijakan yang diambil oleh Donald Trump dan legitimasi politiknya di dunia internasional. Guna mempermudah pembahasan, tulisan ini akan penulis bagi dalam tiga bagian. Bagian pertama akan membahas tentang teori legitimasi sebagai tinjauan pustaka. Bagian berikutnya akan memaparkan meode penelitian yang digunakan dalam tulisan ini. Bagian ketiga ialah penjelasan mengenai hasil dan pembahasan yang berisi paparan tentang krisis legitimasi politik Donald Trump dan kaitannya dengan supremasi politik AS dunia internasional. Bagian terakhir ialah kesimpulan. 


\section{Teori Legitimasi}

Tulisan ini berupaya untuk membaca legitimasi politik Presiden Donald Trump dalam kancah politik global dan di dunia Islam secara lebih khusus, maka landasan teori yang dibangun untuk membaca hal tersebut adalah teori tentang legitimasi. Legitimasi biasanya sekadar didefinisikan sebagai ‘sesuatu yang sah'. Dengan demikian, sangat penting untuk membedakan antara kekuasaan dan otoritas. Legitimasi adalah kualitas yang mengubah kekuasaan yang telanjang menjadi otoritas yang sah; ia memberikan sifat wibawa yang mengikat pada perintah atau komando, memastikan bahwa ia dipatuhi karena hal tersebut merupakan suatu tugas dan bukan karena ketakutan. Tentu saja terdapat hubungan yang sangat erat antara legitimasi dan otoritas karena kedua istilah ini seringkali digunakan secara sinonim. Namun, seperti yang paling sering digunakan, orang-orang dikatakan memiliki otoritas, sedangkan sistem politiklah yang digambarkan sebagai sesuatu yang memiliki legitimasi (Heywood, 2015: 214).

Ian Hurd mendefenisikan legitimasi sebagai "The normative belief by an actor that a rule or institution ought to be obeyed. It is a subjective quality, relational between actor and institution, and defined by the actor's perception of the institution" (Hurd, 1999: 381). Dalam pemikiran Eropa di abad pertengahan, misalnya, legitimasi digambarkan sebagai orang yang memmipin sesuai dengan hukum dan Kehendak Tuhan (the Will of God), kebalikan dari kepemimpinan tiran (Weigand, 2015: 9).

Tentu saja, terdapat perselisihan pandangan mengenai legitimasi. Namun demikian makna yang banyak digunakan adalah yang berasal dari Weber. Weber memaknai legitimasi sebegai keyakinan mengenai 'hak untuk memerintah', keyakinan pada legitimasi. Dengan kata lain, ketika rakyatnya siap untuk mematuhinya, sistem pemerintahan dapat dikatakan sebagai sistem pemerintahan yang mempunyai legitimasi politik (Heywood, 2015: 214-215). Dengan demikian, semakin tinggi tingkat kepatuhan rayat terhadap pemimpinnya, maka semakin tinggi tingkat legitimasi politik dari pemimpin tersebut. Tingkat kepatuhan tersebut tidak terlepas dari sejauh mana suatu pemerintahan mampu memberikan nilai manfaat yang lebih daripada yang lainnya. faktor umumnya lainnya yang dapat dilihat dari sumber legitimasi adalah sejauh mana pemerintahan tersebut 
memberikan nilai keadilan kepada semua pihak. Dengan demikian, pemerintahan yang melanggengkan atau memperburuk ketidakadilan (ketidaksetaraan), misalnya dalam pemerintahan global, dianggap memiliki legitimasi politik yang rendah (KarlssonVinkhuyzen, 2016).

Jean-jacques Rousseau menyatakan "Yang paling kuat sekalipun tidak akan cukup kuat kecuali mengubah kekuatan menjadi hak dan kepatuhan menjadi kewajiban.” Inilah menguapa sebuah sistem kekuasaan berusaha memeroleh legitimasi atau 'keabsahan', yang memungkinkan mereka untuk menuntut ketundukan dan kerelaan dari

yang dipimpinnya. Singkatnya, legitimasi adalah kunci untuk menjaga stabilitas politik; ia merupakan sumber ketahanan dan keberhasilan bagi sebuah rezim politik, baik nasional maupun global (Heywood, 2014: 137).

Teori legitimasi inilah yang menjadi landasan dalam membaca kebijakan dan langkah politik Donald Trump yang sarat dengan kontroversi sehingga berdampak pada rendahnya pengakuan dunia terhadap kepemimpinan Trump. Tentu saja hal ini berdampak pada legitimasi politik Trump yang juga memengaruhi masa depan supremasi politik global Amerika. Hal tersebut dapat kita lihat dari kebijakan Trump terhadap dunia Islam, kontroversi politik Trump, dalam dan luar negeri, yang kemudian memaksa Trump mengambil langkah politik, yang juga tidak kalah kontroversial, yaitu kebijakan proteksionismenya yang mengguncangkan tatanan politik global.

\section{Metode Penelitian}

Tulisan ini lahir dengan memfokuskan pada kajian kepustakaan. Dalam kajian tersebut, penulis membaca karya-karya yang terkait dengan tema yang penulis angkat, Donald Trump dan Dunia Islam. Sumber-sumber lain dalam bentuk artikel, berita, buku dan rekaman atau video terkait menjadi data penunjang penelitian untuk memahami lebih jauh Donald Trump dan arah kebijakan politiknya, terutama kepada dunia Islam. Datadata yang ada penulis olah dengan menggunakan pendekatan critical reading. Di samping itu, penulis juga beberapa kali mengadakan forum diskusi untuk membahas tema ini sebagai bagian dari upaya pendalaman analisis dan pengayaan pandangan. Karena tulisan ini 
mencoba membaca arah kebijakan Trump yang berdampak pada legitimasi politiknya. Maka penulis melakukan kajian kepustakaan dengan membaca dan mengikuti sepak terjang Trump selama menjadi Presiden AS; memahami makna dari pernyataan-pernyataan Trump dan juga ia bertemu dengan tokoh-tokoh politik internasional.

\section{Hasil dan Pembahasan}

\section{Kontroversi Kebijakan Politik Presiden Donald Trump}

Kehadiran Trump sebagai sosok kuat yang mengerikan, menurut William Liddle, akan meruncingkan benturan peradaban kembali atau clash of civilization, istilah yang pernah dipopulerkan oleh Samuel P. Huntington pada dekade tahun 1990-an. Pernyataannya yang akan memerketat masuknya imigran Muslim ke Amerika yang dicurigai sebagai komunitas yang berpotensi melahirkan terorisme tentu akan meruncingkan clash of civilization tersebut. Itulah mengapa dunia menyambut kemenangan Trump dengan segala kecemasan, berbeda dengan Obama 2008 silam.

Sejak awal, ketegangan politik diprediksi akan muncul itu, yaitu ketegangan hubungan antara Barat (AS) dengan Timur (dunia Islam) sebagaimana rencananya melarang masuk orang Muslim di wilayah AS untuk mewaspadai terorisme. Hal ini langsung dibuktikan oleh Trump tidak lama setelah mendiami White House dengan melarang tujuh warga negara untuk masuk ke AS. Ketujuh warga negara yang dilarang itu di antaranya adalah Iran, Irak, Libya, Somalia, Sudan, Suriah, dan Yaman. Hal ini direspons oleh Mahakamah Federal AS dengan memblokir keputusan Presiden Trump tentang larangan masuk AS bagi warga ketujuh negara tersebut (Kompas, 5/02/2017).

Pernyataan dan langkah politik Trump yang kurang bersabahat dengan dunia Islam menyebabkan hubungan antara Barat dan dunia Islam akan kembali memanas sebagaimana ketegangan hubungan Barat dan dunia Islam pada era George Walker Bush yang dianggap melakukan konspirasi dengan isu World Trade Center (WTC) untuk menyerang negara-negara Islam, Iraq salah satu contohnya yang kini tak kunjung mencapai stabilitas politiknya. Trump akan kembali menyulutkan bara apai kebencian antara Barat dan dunia Islam. 
Pada penghujung tahun 2017, Trump kembali mengguncangkan tatanan politik global, terutama dunia Islam, dengan pernyataan resminya yang mengakui Jerusalem sebagai Ibu Kota Israel. Padahal Jerusalem melalui resolusi Perserikatan BangsaBangsa (PBB) 181 tahun 1947 ditetapkan sebagai kota di bawah wewenang internasional. Ketetapan yang memungkinkan kaum Muslim, Nasrani, dan Yahudi melakukan ibadah keagamaannya. Hal itu karena Jerusalem adalah satu kota tiga iman (Karen Amstrong).

Pernyataan Trump tersebut disambut beragam dari banyak pemimpin dunia, Perdana Menteri Israel tentu saja senang dengan hal ini dengan mengatakan bahwa, "Sebuah keputusan yang berani dan adil." Namun tidak sedikit yang mengecam Trump dengan sikapnya itu. Presiden Indonesia juga merespons dengan mengatakan bahwa, "Pengakuan sepihak tersebut telah melanggar berbagai resolusi dewan keamanan PBB dan Majelis Umum PBB," Presiden Perancis mengatakan bahwa ini sangat "Disesalkan." Secara umum, pandangan pemimpin-pemimpin politik dunia melihat bahwa pernyataan Trump tersebut mengganggu proses perdamaian antara Israel-Palestina (Kompas, 9/12/2017).

Dunia internasional langsung merespons pernyataan Trump tersebut. Organisasi Konferensi Islam (OKI) yang beranggotakan 57 negara segera melaksanakn Konferensi Tingkat Tinggi di Istanbul, Turki. Hasilnya, negara-negara anggota OKI sepakat untuk tidak ikut dengan Trump mengenai Jerusalem. Negara-negara anggota Uni Eropa juga mengecam apa yang dilakukan oleh Amerika di bawah Trump. Presiden Perancis, Emmanuel Macron, mengatakan bahwa ini sangat "Disesalkan." Secara umum, pandangan pemimpin-pemimpin politik dunia melihat bahwa pernyataan Trump tersebut mengganggu proses perdamaian antara Israel-Palestina.

Kamis, 21 Desember 2017, Majelis Umum PBB menggelar voting yang menyerukan agar AS menarik pengakuannya terhadap Jerusalem sebagai ibu kota Israel. Hasilnya, 128 negara menyetujui resolusi tersebut, 9 negara menolak, 35 negara abstain, dan 21 negara anggota tidak menggunakan hak suaranya. Hasil sidang Majelis Umum PBB ini menunjukkan bahwa langkah politik Donald Trump sangat tidak populis di kancah 
politik internasional. Bahkan negara-negara sekutunya di Uni Eropa juga tidak sejalan dengan AS.

AS di bawah kepemimpinan Trump akan mengalami krisis legitimasi politik dan perlahan-lahan akan kehilangan supremasi politiknya di kancah politik global kontemporer. Beberapa bulan sebelumnya Angela Merkel, Kanselir German, pernah mengatakan bahwa Uni Eropa harus mulai berpikir untuk tidak tergantung dengan Amerika. Sinyal politik yang mesti dibaca dengan baik oleh Trump dan para penentu kebijakan di negara kampiun demokrasi tersebut untuk kelangsungan supremasi politiknya. Jika salah membaca, ini bisa menjadi awal keruntuhan supremasi politik Amerika di kancah politik internasional.

Tidak bisa dinafikan bahwa bukanlah perkara yang mudah untuk mengisolasi Amerika dalam kancah politik global saat ini sebab Amerika memiliki segalanya. Amerika kuat dari segi ekonomi, kuat persenjataan militernya, kuat jaringan politik globalnya, dan unggul dalam pengembangan ilmu pengetahuan dan teknologi. Tetapi ketika Angela Merkel sudah mulai berpikir untuk tidak tergantung dengan Amerika, maka sudah saatnya pula bagi negara-negara dunia Islam, OKI, untuk berpikir mengurangi tingkat ketergantungannya terhadap Amerika Serikat. Selagi sebagian besar negara-negara di dunia ini masih sangat tergantung dengan Amerika, maka Amerika tidak akan mendengarkan aspirasi dunia internasional, terutama dalam kasus Israel-Palestina. Maka bagi Trump, sekalipun hasil voting Majelis Umum PBB yang mayoritas menolak pengakuannya atas Jerusalem sebagai ibu kota Israel, Trump tidak akan memedulikannya. Mungkin bagi Trump, biarkan saja dunia 'menggonggong,' AS di bawah kepemimpinannya akan tetap berlalu (mengakui Jerusalem).

Oleh karena itu, perjuangan diplomatik ke depan adalah perjuangan untuk mengurangi tingkat ketergantungan dengan Amerika Serikat. Apa yang pernah dikatakan oleh Angela Merkel perlu disambut dengan langkah-langkah diplomatik oleh negaranegara yang bergabung dalam OKI. Ini juga bukanlah perjuangan yang mudah karena kita harus memulai dengan membangun ilmu pengetahuan dan teknologi, membangun ekonomi yang kuat, membentengi diri dengan persenjataan yang kuat pula. 
Setidaknya, sikap politik Trump tersebut berdampak pada dua hal. Pertama, Trump merusak segala upaya damai Israel-Palestina yang selama ini dilakukan oleh berbagai pihak. Kehadiran Trump yang sangat jelas keberpihakannya kepada Israel tidak akan membuahkan negosiasi politik yang baik karena tidak adanya netralitas. Kedua, konflik Israel-Palestina bukan hanya perhatian dunia Arab, tetapi dunia Islam secara global. Tentu saja Trump dilihat telah melukai kembali dunia Islam. Terlebih sejak awal kampanyenya untuk menjadi orang nomor satu di negara Paman Sam tersebut telah melontarkan pernyataan-pernyataan yang mendiskreditkan Islam. Kurang dari setahun setelah resmi dilantik, Trump memberikan pengakuan kepada Jerusalem sebagai Ibu Kota Israel, sebelumnya melarang tujuh warga negara untuk masuk AS.

Oleh karena itu, langkah politik yang telah dan akan diambil oleh Trump kembali akan meruncingkan ketegangan hubungan antara Barat, terutama AS, dengan dunia Islam. Kembali akan terjalin hubungan yang saling mencurigai dan membenci. Ini juga akan berdampak dengan meningkatnya radikalisme dan terorisme di dunia Islam karena sikap Trump yang menyudutkan dunia Islam. Itulah dampak tatanan politik global, terutama dengan dunia Islam, dari hasil daur ulang demokrasi Amerika Serikat 2016 lalu. Seandainya Hillary yang terpilih pada pilpres AS tahun lalu, tentu saja tatanan politik global tidak akan mengalami gejolak seperti saat ini.

Donald Trump sendiri saat ini telah menjadi orang terkuat di dunia mengingat ia memimpin negara adi daya, super power. Tidak heran, sejak kemunculannya dalam konvensi partai Republik, sosoknya telah menjadi perhatian dunia internasional. Tentu saja untuk menimbang dan mengantisipasi apa yang nanti akan dilakukan Trump, Presiden ke45 Amerika Serikat (AS) ini. Trump sejak awal kemunculannya adalah tokoh yang sangat kontroversial. Hal itu telah melekat dalam dirinya. Bahkan setelah dirinya dilantik menjadi Presiden AS dan kemudian mendiami White House (Gedung Putih). Trump tak hentihentinya memberikan pernyataan kontroversial dan menghebohkan dunia internasional. Seolah kontroversi adalah daya pikat darinya dan keberhasilannya mendiami White House. Setelah dinyatakan menang dan tinggal menunggu pelantikan dirinya, 20 Januari 2017, Trump mengeluarkan pernyataan yang meragukan hasil temuan Central Inteligence of America 
(CIA) yang menduga Vladimir Putin, Presiden Rusia, ikut terlibat membantu kemenangan dirinya. Itulah Donlad Trump, Presiden Amerika saat ini. Sosok kuat yang mengerikan dunia, demikian William Liddle, Professor Emeritus Ohio State University, melihat sosoknya (Kompas, 15/10/2010).

\section{Krisis Legitimasi Pemerintahan Donald Trump}

Dalam Kamus Besar Bahasa Indonesia (KBBI), 'legitimasi’ dimaknai, salah satunya, sebagai pernyataan yang diakui keabsahannya; pengesahan. Krisis legitimasi politik berarti suatu pemerintahan tidak mendapatkan pengakuan publik secara luas. Menurut Jurgen Habermas, krisis legitimasi muncul ketika loyalitas dan kepatuhan massa tidak dapat dipelihara dengan baik. Namun demikian, krisis legitimasi belum tentu menjadi krisis sistem, melainkan "krisis identitas", yaitu ancaman langsung bagi integrasi sosial (McCarthy, 2006: 479).

Krisis legitimasi inilah yang nampaknya membayangi AS di bawah kepemimpinan Trump. Krisis legitimasi itu mulai terlihat, salah satunya, ketika tim Trump tidak mampu menghadirkan musisi "Kelas A" pada malam menjelang pelantikannya. Hal berbeda dari Barack Obama yang mampu menghadirkan bintang 'raksasa' (Kompas, 21/01/2017). Jumlah warga AS yang menghadiri pelantikan Obama juga dua kali lebih banyak dari jumlah warga yang menghadiri pelantikan Trump. Sedikitnya jumlah warga yang menghadiri pelantikan itu juga menjadi sinyal rendahnya legitimasi politik yang dimiliki Trump. Selain itu, terjadi demonstrasi penolakan di mana-mana di AS pada hari pelantikan (Kompas, 21/01/2017). Bahkan Mahakamah Federal AS memblokir keputusan Presiden Trump tentang larangan masuk AS bagi warga tujuh negara (Kompas, 5/02/2017).

Itulah dampak politik yang diterima oleh Trump dengan sikap kontroversialnya. Nampaknya jalan Trump tidak sejalan dengan jalan yang dikehendaki oleh sebagian besar rakyat Amerika. Terlebih dengan pilihan politiknya yang memilih bersahabat dengan Presiden Rusia, Vladimir Putin. Hubungan Trump-Putin berpotensi akan menjadi hubungan politik kedua pemimpin yang tidak merepresentasikan warga dan negaranya. Tentu saja semua itu berpengaruh terhadap legitimasi politik atau kepatuhan politik yang dimilikinya. Trump mestinya berupaya menjaga legitimasi politik yang 
dimilikinya karena jika ia kehilangan hal tersebut ia akan kehilangan power sebagai presiden. Bukankah dalam teori politik dikatakan bahwa orang yang mempunyai kekuasaan adalah orang yang mampu menguasai pikiran dan tindakan orang lain? Dalam sistem politik yang demokratis, hal itu dapat diraih dengan legitimasi politik yang tinggi.

Tanpa legitimasi politik, seturut Habermas, yang terjadi adalah disintegrasi sosial. Akan terjadi ketidakpatuhan sosial dan bisa jadi memunculkan perlawananperlawanan atau bahkan pemberontakan. Demonstrasi yang menentang kebijakan Trump dari berbagai elemen masyarakat menjadi sinyal awal munculnya perlawanan tersebut dan juga perlawanan yang dilakukan oleh Mahkamah Federal. Inilah ancaman politik dari sikap kontroversial Trump. Kontroversi yang mengarah pada krisis legitimasi dan kemudian menjadi ancaman integrasi sosial, ancaman stabilitas politik. Inilah yang dihadapi oleh AS saat ini di bawah Trump, di negara kampiun demokrasi di dunia.

Sejak resmi dilantik menggantikan Barack Obama untuk mendiami White House (Gedung Putih) 20 Januari 2017, Trump kerap kali mengeluarkan pernyataan politik yang cukup kontroversial dan di luar mainstream gaya politik pemimpin AS pada umumnya. Trump adalah Presiden AS yang cukup aktif memberikan pernyataan-pernyataan politik melalui akun twitternya. Berbeda dari pemimpin dunia pada umumnya yang jarang menghabiskan waktu melalui media sosial karena kesibukannya. Trump selalu saja punya waktu untuk 'berciut' melalui media sosial yang mana dari ciutannya tersebut menghebohkan jagat politik internasional.

Tidak heran jika banyak yang memandang bahwa terpilihnya Donald Trump sebagai Presiden Amerika Serikat merupakan hasil dari sebuah proses demokratisasi yang cacat. Demokrasi tidak menjadi ajang untuk mencari figur-figur terbaik sebagai pemimpin, melainkan memberi jalan bagi figur seperti Donald Trump untuk menjadi orang nomor satu di negeri Paman Sam tersebut dan bahkan dunia internasional. Maka dari itu, sejak resmi mendiami White House, dunia internasional telah disuguhi banyak berita kontroversial dari sosok Donald Trump. Dimulai dari pernyataannya yang meragukan hasil temuan Central Inteligence of America (CIA) yang menduga Vladimir Putin, Presiden Rusia, ikut terlibat membantu kemenangan dirinya, keputusannya yang melarang tujuh warga negara 
masuk AS karena dianggapnya berpotensi menjadi teroris sehingga menghadirkan perseteruan antara dirinya dengan Mahakamah Federal AS yang memblokir keputusan tersebut. Terakhir, Trump mengambil kebijakan proteksionisme yang memicu perang dagang antara AS dan China.

\section{Pemerintahan Donald Trump dan Supremasi Politik Amerika Serikat}

Tidak lama setelah dinyatakan menang dalam pilpres Amerika 2016, terkuak ke media sosial mengenai salah satu rahasia penting di balik kemenangan Trump, tokoh kontroversial itu. Ternyata ada peran Rusia, terutama Presiden Vladimir Putin, yang membantu Trump dalam mengalahkan kandidat yang diunggulkan dunia internasional. Putin membantu Trump dalam menjatuhkan popularitas Hillary Clinton dengan menginstruksikan menyebarkan berita-berita yang merusak reputasi Hillary Clinton. Trump dan Putin memang dikenal mempunyai hubungan yang cukup dekat. Kedua tokoh ini adalah rekanan bisnis. Sampai saat ini, keterlibatan Rusia dalam kemenangan Trump masih menjadi kerikil yang mengganggu kepemimpinan Trump, termasuk mengganggu legitimasi politiknya, baik di dalam negeri maupun dengan negara-negara sekutu AS di Eropa.

Tidak bisa dimungkiri bahwa terjadi perebutan pengaruh dan ideologi antara Amerika dan Rusia dalam kancah politik internasional saat ini. Rusia, salah satu kekuatan politik Uni Soviet dulu, tentu menyimpan dendam sejarah ketika kekuatan politiknya berhasil dihancurkan oleh Amerika Serikat sehingga berakhirlah era Perang Dingin pada awal tahun 1990-an. Uni Soviet terpecah menjadi beberapa negara sehingga tidak lagi punya kekuatan politik dalam menghadapi Amerika Serikat. Francis Fukuyama kemudian menulis buku yang berjudul The End of History and the Last Man, terbit pada tahun 1992.

Di Indonesia, buku ini sudah dikonsumsi secara luas dan termasuk salah satu buku bacaan penting dalam kajian ilmu sosial dan politik. Buku ini juga sudah diterjemahkan ke dalam bahasa Indonesia dengan judul Kemenangan Kapitalisme dan Demokrasi Liberal. Intinya adalah bahwa setelah keruntuhan Uni Soviet, tidak ada lagi ideologi politik global yang mampu menyaingi ideologi kapitalisme dan demokrasi liberal yang diusung oleh Amerika Serikat (Fukuyama, 2001). Perang Dingin berakhir dengan 
ditandai kemenangan bagi pihak Amerika dengan kapitalismenya, serta kekalahan di pihak Uni Soviet dengan ideologi sosialismenya. Supremasi politik global inilah yang selalu dipertahankan oleh Amerika hingga saat ini.

Benarkah tesis Fukuyama bahwa tidak ada lagi ideologi yang mampu menandingi ideologi kapitalisme dan demokrasi liberal yang diusung oleh Amerika dalam kancah politik global? Bahwa Amerika hari ini masih menjadi negara superpower itu benar, tetapi jika dikatakan bahwa sosialisme yang dulu diusung oleh Uni Soviet telah berakhir dan tidak lagi punya kekuatan di hadapan kapitalisme global sepertinya kurang tepat. Rusia kini sedang memasuki fase kebangkitan di bawah kepemimpinan Vladimir Putin. Rusia juga secara terang-terangan mengambil sikap yang berhadap-hadapan dengan Amerika Serikat dalam berbagai kasus dan isu-isu global. Dalam kasus Iran, misalnya, baik itu pada era George Walker Bush maupun pada era Barack Obama yang berakhir 20 Januari 2017, Rusia, bekerja sama dengan Tiongkok, selalu berada pada barisan paling di depan dalam memveto sanksi yang dijatuhkan oleh PBB untuk Iran yang diprakarsai oleh Amerika.

Dalam kasus Suriah yang masih terus bergejolak hingga saat ini, dampak dari The Arab Spring 2011 lalu, Rusia kembali berhadap-hadapan secara langsung dengan Amerika Serikat. Dalam kasus Suriah, Amerika berada di balik kelompok oposisi untuk menggulingkan rezim Bashar al-Assad, sementara Rusia, juga ada Iran, berada di belakang rezim Assad. Amerika dan Rusia pun kerap kali saling menuding dalam penyelesaian kasus Suriah. Pertarungan Rusia versus Amerika di Timur Tengah, terutama dalam kasus Suriah, tentu tidak terlepas dari faktor sejarah, ideologi, politik, dan ekonomi. Hubungan AmerikaRusia pun selalu diwarnai dengan ketegangan. Terlebih Rusia memberikan suaka politik kepada Edward Snowden, mantan anggota NSA, untuk tinggal di Rusia. Rusia pun dianggap semakin tidak bersahabat dengan Amerika. Amerika juga kerap kali mengecam Rusia dalam kasus pencaplokan Crimea. Hal ini dianggap melanggar norma hukum internasional.

Hubungan Amerika-Rusia yang kurang harmonis itulah yang memantik Hillary Clinton mengeluarkan pernyataan politik yang memertanyakan legitimasi politik Putin ketika tepilih kembali menjadi Presiden pada tahun 2012 silam. Pernyataan Hillary 
itu mengusik bagi Putin dan mendapatkan momentum politik dalam pemlihan Presiden Negeri Paman Sam 8 November 2016. Dendam politik Putin kepada Hillary dilampiaskannya dengan membantu kemenangan Trump, yang memang secara personal mempunyai hubungan yang cukup dekat dengannya. Menjelang pergantian tahun, dari 2016 ke 2017, ketegangan hubungan Amerika dan Rusia kembali memanas setelah Amerika mengusir diplomat Rusia dari Amerika. Semua berawal dari terkuaknya ke publik akan keterlibatan Putin dalam pemenangan Trump. Amerika Serikat sebagai negara adidaya dunia merasa dilecehkan supremasinya oleh langkah politik yang diambil oleh Putin karena berani ikut campur dalam urusan politik dalam negeri negara kampiun demokrasi tersebut.

Sinyal kedekatan Trump dengan Putin dan arah kebijakan politiknya mulai kian jelas ketika menunjuk Rex W Tillerson, CEO Exxon Mobil, untuk menduduki posisi menteri luar negeri dalam kabinetnya nanti. Rex W Tillerson dikenal mempunyai hubungan yang cukup dekat dengan Putin (McNamara, 2017: 8., dan Kompas, 27/12/2016). Hal ini dapat dibaca bahwa Trump tidak akan melihat Putin dan Rusia sebagai musuh ideologis dalam kancah politik global. Trump tidak menempatkan Putin dan Rusia sebagai tokoh dan negara yang akan menggeser supremasi politik Amerika dalam percaturan politik global.

Pada aspek inilah Trump akan menghadapi persoalan. Jika Trump tidak menyadari bahwa Amerika dan Rusia kini kembali pada era 'neo-Perang Dingin', maka Trump akan mendapatkan resistensi internal. Apakah dari House of Representative atau dari rakyat itu sendiri. Doktrin kuat dalam kultur politik Amerika adalah bagaimana memertahankan hegemoni dan supremasi politiknya di kancah internasional. Apa yang dilakukan Rusia dengan melakukan peretasan untuk memenangkan Trump dilihat oleh Amerika sebagai sinyal bahwa Rusia mulai berani mengusik supremasi politik Amerika. Sekalipun peretasan itu menguntungkan Trump menuju Gedung Putih, tetapi secara institusi hal tersebut merupakan langkah yang tidak 'menghormati' Amerika sebagai negara adidaya. Oleh karena itu, arah kebijakan Trump yang dekat dengan Rusia berpotensi menjadi kebijakan politik yang tidak merepresentasikan Amerika dan rakyatnya. Trump 
akan menemukan kesulitan dalam menggiring Amerika dan rakyatnya untuk 'bersahabat' dengan Rusia. Hal itu karena kepentingan utama bagi Amerika adalah memertahankan supremasi politiknya dalam kancah politik global.

Terkait dengan ini, Scott McClellan sudah menuliskannya dalam bukunya yang berjudul What Happened, Indside the Bush White House and Washington's Culture of Deception. Intinya adalah bahwa ada arus kekuatan politik di Gedung Putih (White House) yang tidak mampu dilawan oleh presiden sekalipun. Bush menghadapi itu, termasuk Obama. Nampaknya, Trump juga akan menghadapi itu dan sinyalnya adalah ketika Amerika mengusir Duta Besar Rusia dari Washington menjelang pergantian tahun sekalipun Trump hanya menunggu tanggal 20 Januari 2017 lalu untuk dilantik secara resmi sebagai orang nomor satu di negara Paman Sam tersebut. Ini menjadi sinyal penting bahwa arus kekuatan politik di Gedung Putih tidak tunduk atau tidak sejalan dengan garis politik yang akan dibangun oleh Trump nantinya yang bersahabat dengan Rusia di bawah kepemimpinan Putin. Singkatnya, kedekatan hubungan antara Trump dengan Putin tidak bisa dilihat sebagai representasi hubungan antara Amerika sebagai suatu Negara dengan Rusia.

\section{Proteksionisme Trump dan Masa Depan Supremasi Politik AS}

Donald Trump adalah Presiden Amerika Serikat (AS) yang cara berpikirnya keluar dari mainstream cara berpikir pemimpin AS pada umumnya. Itulah yang membuatnya sebagai presiden yang menang dengan tren populisme tetapi tidak mempunyai legitimasi politik yang kuat, baik itu di tataran domestik maupun dunia internasional. Salah satu yang menjadi faktor lemahnya legitimasi politik Trump, sekaligus kontroversial, adalah adanya intervensi Rusia (terutama Vladimir Putin) di balik kemenangannya. Ini juga yang berada di luar mainstream atau garis politik AS sebagai negara super power di dunia. Rusia, yang dulu dikenal Uni Soviet, adalah negara pewaris ideologi sosialisme yang merupakan lawan dari ideologi kapitalisme global yang dipimpin oleh Amerika Serikat hingga berakhirnya Perang Dingin. Meskipun sosialisme Uni Soviet runtuh pada awal tahun 1990an yang dilihat oleh Francis Fukuyama sebagai akhir dari sejarah perang ideologi global (The End of History and the last Man). Fukuyama berpandangan bahwa setelah runtuhnya Uni Soviet maka tidak ada lagi ideologi yang mampu menyaingi ideologi kapitalisme global yang dipimpin oleh AS. 
Boleh jadi Fukuyama tidak melihat Rusia akan kembali bangkit dan menjadi bayang-bayang dari supremasi politik Amerika.

Pembacaan Fukuyama nampaknya tidak terlalu tepat karena Rusia, terutama di bawah kendali Putin, kembali menjelma sebagai negara kuat yang siap menggantikan supremasi politik yang dikendalikan oleh Amerika. Dalam beberapa kasus, Rusia berani mengambil sikap politik yang berseberangan dengan Amerika. Hal itu dapat kita lihat dalam perang yang masih berlangsung di Suriah hingga hari ini. Singkatnya, bisa dikatakan bahwa Rusia sebagai pemimpin negara sosialis masih dilihat sebagai representasi lawan ideologis kapitalisme yang dipimpin AS. Tetapi anehnya, Trump justru menikmati kerja sama dengan Putin. Dalam wawancara dengan CNN, Trump mengatakan "Putin dan Obama tidak saling menyukai sehingga sulit bernegosiasi, namunSaya mungkin akan sangat cocok dengannya. Dan saya rasa tidak akan ada masalah seperti yang ada sekarang" (Sahrasad, 2017: 8). Pada hari terpilihnya sebagai Presiden AS, Trump menunjukkan sikap respeknya kepada pemimpin Rusia, Putin (McNamara, 2017: 5).

Inilah langkah politik Trump yang di luar dari mainstream politik pemimpin AS pada umumnya. Selain itu, politik proteksionisme yang diusung oleh Trump juga berada di luar garis politik yang umumnya diambil oleh pemimpin yang mendiami White House (Gedung Puth), penganut paham liberalisme ekonomi. Trump kelihatannya tidak menganut paham tersebut.

\section{Peraturan Proteksionisme}

Kemenangan Donald Trump di AS membuktikan kebangkitan populisme dengan semboyan 'America First' untuk melawan para elite dan kemapanan di negeri itu (Sahrasad, 2017: 3). Sejak awal Trump menunjukkan arah kebijakannya ke inward-looking yang diisyaratkan dengan keinginan Trump untuk meninjau semua perjanjian perdagangan, kesepakatan Trans-Pacific Patnership (TPP), menarik modal AS di luar negeri dan mengenakan penalti perusahaan AS yang memberi pekerjaan kepada bangsa lain. Ini tentu menjadi kabar buruk dan mencemaskan bagi ekonomi dunia, terutama di tengah melambatnya pertumbuhan perdagangan global yang diperkirakan hanya sekitar 1,7\% pada tahun 2016 (Sahrasad, 2017: 4). 
Kebijakan inward-looking terbukti ketika Donald Trump akhirnya mengesahkan peraturan soal pengenaan bea masuk (ke AS) pada hari Kamis waktu setempat, 08 Maret 2018. Dengan peraturan tersebut, tarif bea masuk 25 persen untuk baja dan 10 persen untuk aluminium (Kompas, 10/03/2018). Langkah proteksionisme Trump ini tentu saja bertentangan dengan paham liberalisme ekonomi yang selama ini dianut oleh Amerika dan sekutunya.

Amerika Serikatlah bersama dengan Inggris dan 22 negara lainnya yang memprakarsai lahirnya 'sistem Bretton Woods' pada Agustus 1944 yang melahirkan tiga lembaga dengan corak ekonomi liberal. Tiga lembaga itu adalah International Monetary Fund (IMF), International Bank for Reconstruction and Developmen (IBRD) yang kemudian dikenal dengan World Bank (Bank Dunia), dan World Trade Organization/WTO (Heywood, 2017: 831-833). Amerika selama sekian abad menikmati kemakmuran dan mampu meraih supremasi politik globalnya karena dilayani oleh sistem tersebut, salah satu dari kritik Joseph Stiglitz.

Keyakinan dari paham ekonomi liberal adalah bahwa ekonomi akan berjalan dengan baik ketika dibiarkan bebas oleh pemerintah. Hal ini diyakini berlaku pada level internasional maupun nasional (Heywood: 834). Selama sekian abad lamanya Amerika mendoktrinkan paham ini kepada negara-negara dunia ketiga untuk diterapkan. Amerika tentu saja mendapatkan banyak keuntungan finansial dari diterapkannya paham tersebut sebagaimana dikatakan oleh Stiglitz bahwa IMF sebenarnya merespons 'kepentingankepentingan' dan ideologi masyarakat finansial barat (Heywood: 842).

Tidak heran jika nominasi sepuluh orang-orang terkaya di dunia selalu didominasi oleh warga negara Amerika Serikat karena IMF hadir untuk melayani kepentingan finansialnya. Namun kini Trump mulai meragukan sistem tersebut. Trump melihat bahwa liberalisme ekonomi mengancam pasar domestik di AS sehingga ia harus mengambil langkah yang bercorak Keynesian (negara mengintervensi pasar). Trump melihat bahwa liberalisme ekonomi yang selama ini dianut oleh AS dan sekutunya banyak merugikan AS karena memungkinkan baja dan aluminium produksi AS tidak mampu terserap di pasar domestik dengan masuknya baja dan aluminium produsi dari negara lain. 
Pada sisi yang lain, ini juga menjadi indikasi ketidakmampuan pasar domestik AS dalam bersaing dengan pasar dari luar di mana liberalisme ekonomi menuntut daya saing yang tinggi. Maka perlu bagi Trump untuk melindungi pasar domestiknya sehingga keluarlah peraturan bea masuk tersebut. Pemerintahan Trump ingin paling sedikit 80 persen baja dan aluminium produksi AS terserap di pasar dalam negeri (Kompas, 10/03/2018).

Peraturan yang dikeluarkan Trump tersebut menuai kecaman dan respons negatif dari berbagai negara, termasuk dari sekutunya Uni Eropa. Uni Eropa bersiap untuk menggugat AS ke W'TO karena hal ini dianggap bertentangan dengan aturan dalam WTO di mana AS sendiri yang menjadi salah satu prakarsa dari lahirnya perjanjian Breeton Woods (lahirnya IMF, WB, dan WTO). Jika AS tidak memedulikan respons dari negaranegara Uni Eropa, maka kebijakannya tersebut akan dibalas dengan Uni Eropa sehingga yang terjadi adalah perang dagang global dan ini tentu sangat berbahaya dalam ekonomi politik global (Kompas, 10/03/2018).

\section{Supremasi Politik AS}

Proteksionisme yang diambil oleh Trump tersebut membuat para sekutunya gerah dan tidak nyaman. Hal ini tentu saja menjadi ancaman bagi AS dalam memertahankan supremasi politiknya. Sudah sejak lama Kanselir German, Angela Merkel, mengutarakan bahwa UE harus berlajar untuk tidak tergantung dengan AS. Pernyataan Merkel tersebut ketika merespons pernyataan Trump bahwa AS terlalu banyak menghabiskan uang untuk menjaga keamanan negara-negara sekutu, termasuk UE. Oleh karena itu, AS di bawah Trump berpikiran bahwa UE harus mampu menjaga dan membiayai keamanannya sendiri tanpa harus tergantung dengan Amerika.

Kini, Trump kembali mengusik sekutunya, Uni Eropa, dengan peraturan bea masuk untuk produk baja dan aluminium yang direspons dengan negative oleh UE. Oleh karena itu, langkah politik yang diambil oleh Trump tersebut menguntungkan pasar domestik AS tetapi itu akan menjadi ancaman untuk memertahankan supremasi politiknya dalam kancah politik global. Apakah Trump akan menjadi awal dari berakhirnya supremasi politik AS di dunia internasional? Waktu yang akan menjawab. Yang pasti, beberapa negara sekutu AS mulai gerah dengan Trump dan memaksanya berpikir untuk tidak tergantung 
dengan AS. Jika hal itu terjadi, maka perlahan-lahan supremasi politik AS akan berakhir. China dan Rusia telah bangkit dan bersiap untuk merebut 'mahkota' tersebut yang selama ini berada dalam genggaman AS.

Bahkan China berani mengambil sikap secara terang-terangan dalam merespons kebijakan proteksionisme Trump. Sehingga perang dagang yang terjadi akibat dari proteksionisme Trump akan memperhadapkan antara dua negara super power di dunia, Amerika versus China. Inilah yang menjadi kekhawatiran global jika perang dagang kedua negara ini tidak dapat diselesaikan. Dampaknya adalah pada perekonomian global.

\section{Kesimpulan}

Donald Trump adalah Presiden AS yang dipilih melalui proses yang demokratis. Oleh karena itu, sekalipun sosoknya kontroversial, rakyat AS dan dunia harus menerima dia sebagai presiden AS yang sah sekalipun dengan berbagai resiko dan konsekuensi yang mesti diterima. Namun demikian, hadirnya Donald Trump sebagai aktor penting dan utama dalam panggung politik global, dengan segala kontroversi yang melekat padanya, setidaknya menyebabkan krisis legitimasi politik dalam tiga aspek utama.

Pertama, isu intervensi Rusia dalam proses daur ulang demokrasi yang memenangkan dirinya membuatnya selalu dirongrong oleh elite-elite politik yang konservatif dan ini menyebabkan pengakuan rakyat AS terhadapnya rendah. Kedua, kebijakan Trump yang dinilai kurang bersahabat dengan dunia Islam membuat hubungan AS dengan dunia Islam kembali memanas. Trump merusak dan memeruncing kembali hubungan AS dengan dunia Islam yang sebelumnya dibangun oleh Obama. Kebijakankebijakan dan pernyataan politik Trump kerak kali membuat dunia Islam merasa tidak nyaman, termasuk dengan mengakui Jerusalem sebagai ibu kota Israel. Hal ini tentu mengganggu pengakuan politik (legitimasi) dari dunia Islam terhadap Trump dan Amerika.

Ketiga, sosok kontrovesial dan di luar mainstream gaya kepemimpinan AS pada umumnya membuat para sekutu AS gerah dengan Trump sehingga ada wacana untuk mengurangi tingkat ketergantungan dengan AS. Termasuk dengan hubungan baiknya dengan Vladimir Putin serta kebijakan proteksionismenya. Krisis legitimasi ini tentu 
menjadi ancaman bagi supremasi politik AS dalam kancah politik global. Oleh karena itu, rakyat AS harus membayar mahal hasil pilihannya dalam daur ulang demokrasi 2016 silam. Di satu sisi, Trump memang populer tetapi tidak mempunyai legitimasi politik yang kuat, baik di dalam negeri maupun di dunia internasional.

\section{Daftar Rujukan}

\section{Buku}

Fukuyama, Francis. (2001). Kemenangan Kapitalisme dan Demokrasi Liberal. Yogyakarta: Qalam.

Heywood, Andrew. (2015). Pengantar Teori Politik. Yogyakarta: Pustaka Pelajar.

Heywood, Andrew. (2014). Politik. Yogyakarta: Pustaka Pelajar.

Heywood, Andrew. (2017). Politik Global. Yogyakarta: Pustaka Pelajar.

Hurd, Ian. (1999). Legitimacy and Authority in International Politics. International Organization 53, 2, Spring 1999, pp. 379-408.

Karlsson-Vinkhuyzen, S. I. (2016). Legitimacy. In C. Ansell \& J. Torfing (Eds.), Handbook of Theories of Governance (pp. 194-204): Edward Elgar.

Liddle, William. (2016). Orang Kuat yang Mengerikan. Kolom Opini, edisi 15 Oktober.

McCarthy, Thomas. (2006). Teori Kritis Jurgen Habermas. Yogyakarta: Kreasi Wacana.

McNamara, Eoin Michael. (2017). Between Trump's America and Putin's Russia: Nordic-Baltic Security Relations amid Transatlantic Drift. Source: Irish Studies in International Affairs, (2017), pp. 1-26. Published by: Royal Irish Academy.

Sahide, Ahmad. (2018). Donald Trump; Islamic World and Globally Political Order of Indonesian Perspective. Istanbul: Academicsiera.

Weigand, Florian. (2015). Investigating the Role of Legitimacy in the Political Order of Conflict-torn Spaces. London: International Development.

Wolff, Michael. (2018). Fire and Fury Inside the Trump White House. United State: Little, Brown. 


\section{Jurnal}

Sahrasad, Herdi dan Al Chaidar. (2015). Islam, Fundamentalists \& Democracy: A Perspective from Indonesia. Jurnal Ushuluddin, Vol. 2. No. 4. 2015.

\section{Artikel}

Kompas, Edisi 27 Desember 2016. Dunia Menanti Arah Kebijakan Trump.

Kompas, Edisi 21 Januari 2017. Trump Harus Satukan Rakyat.

Kompas, Edisi 5 Februari 2017. Mabkamah Federal Perintabkan Penghentian Secara Nasional. Kompas, Edisi 9 Desember 2017. Warga Dunia Protes Trump.

Kompas, Edisi 10 Maret 2018. Sekutu AS Minta Dispensasi Tarif. 